\title{
Approach to the Construction of Green Port in Tianjin Port
}

\author{
Guo xu ${ }^{1, a}$, Liu leilei ${ }^{1}$ \\ ${ }^{1}$ Key Laboratory of Environmental Protection in Water Transport Engineering Ministry of Communications, Tianjin Research Institute \\ of Water Transport Engineering, Tianjin 300456, China
}

\begin{abstract}
Transportation is one of the main sources of carbon emission, and it is also an important area for reducing greenhouse gas emission and alleviating climate change. Tianjin port is the largest artificial port in China, and it is also an important port in China. The construction of green port can effectively control the energy consumption and pollutant discharge of the port. From five aspects of improving management ways, strengthening propaganda and training, clean energy utilization, technological transformation and environmental protection, this paper puts forward relevant measures for Tianjin port to build green ports, so as to effectively guide Tianjin port to carry out the construction of green ports.
\end{abstract}

\section{Introduction}

Transportation is one of the main sources of carbon emission, and it is also an important area for reducing greenhouse gas emission and alleviating climate change ${ }^{[1]}$. The State Council of the People's Republic of China has identified the transportation industry as one of the key industries of energy conservation and emission reduction, and it is clearly required to speed up the construction of the transportation system with the characteristics of reducing carbon emissions ${ }^{[2]}$. As an important part of the transportation sector, port industry has played a great role in promoting the development of the national economy, and has also brought certain pressure on energy consumption and pollutant emissions ${ }^{[3]}$.

In order to promote the construction of green ports, the Ministry of transport of the People's Republic of China issued the "Standard for Green port Grade evaluation " (JTS/T105- 4-2013) in April 9, 2013. It is required to be implemented from June 1, 2013. According to the " Standard for Green port Grade evaluation ", green port refers to the port which is adhering to the concept of resource saving and environment-friendly development, actively fulfilling its social responsibilities, and comprehensively adopting technologies and management measures that are conducive to saving resources and energy, protecting environment and ecology and coping with climate change.

Green port Grade can show that the difference of green development level of port and terminal, from low to divided into 3 stars, 4 stars and 5 stars three grades. Meanwhile, the Ministry of transport has given special funding support to green port construction. Tianjin port was listed as the national pilot unit for green port construction in 2013.

\section{Materials and Methods}

According to the requirements of the green port and the actual situation in Tianjin port, the wharf enterprises should carry out the green port construction activities mainly from the following aspects.

\subsection{Improving the Management Level}

Through the development of green port action plan, arrange special funds for the development of green port, released the annual report on the development of green port and a variety of ways, can make the port enterprises enhance port green concept, improve the management level of the green development of port enterprises, effectively guide the green port construction. At the same time, the construction of green port construction departments should be set up, and the corresponding management personnel should be made clear. To carry out the work of energy audit and environmental management system certification. Instituting all kinds of incentive and constraint measures, such as the assessment of green port construction personnel, can effectively improve the management level of green port.

\subsection{Strengthen Personnel Training and Carry Out Green Port Propaganda Activities}

In order to enhance the sense of responsibility for the wharf enterprises and related employees, various forms and means should be used to popularize the knowledge of green port construction.

Through various ways, including strengthening the propaganda, giving full play to the guiding role of public opinion; regular training to carry out energy-saving emission reduction and energy saving technology, 
exchange of experience, and vigorously promote energy conservation and environmental protection of cultural construction, we can improve the whole industry of energy saving and environmental protection consciousness, establish the idea of green development of port.

\subsection{Strengthening the Proportion of Clean energy Application In Port}

The utilization of clean energy is the trend of port development in the future. By improving the technology of "oil to gas" and "oil to electricity" in port RTG and port vehicles, we can use electric energy and natural gas instead of all kinds of fuel to effectively reduce fossil fuel use[4].

At the same time, the manager of the port must vigorously promote the wind power and solar energy application in the port area, and actively support the geothermal energy, ocean energy and other new energy development and utilization in the port, including the local conditions in promoting wind and solar complementary lighting technology, solar bathing and use natural gas as the building heating energy refrigeration system. Through a variety of measures, we can further optimize the structure of the port energy consumption, and improve the use of clean energy and renewable energy[5].

\subsection{Strengthening the Improvement of Port Process $^{[6]}$}

The improvement of port loading and unloading technology is the most direct way to reduce the energy consumption of the port. We should vigorously carry out outdoor and yard lighting, intelligent control technology, application of power grid harmonic pollution control technology and grid reactive power com-pensation technology, equipped with shore based ships and shore power facilities. Besides, for container terminals, crane should mainly use potential energy recovery, energy storage technology or DC drive technology, shore side loading and unloading process. For dry bulk wharf, it mainly includes the application of variable frequency drive or reduction motor operation technology in belt conveyor, the multi station telescopic device in the process of loading, and the application of belt conveyor in the direction of material flow direction and the operation technology of reducing motor.

\subsection{Strengthen the Environmental Protection of the Port}

Environmental protection in port area and surrounding area is one of the most important tasks in green port construction. It mainly includes three aspects: pollution control, comprehensive utilization of resources and ecological protection:

In the field of pollution control, using the water saving equipment recommended by the state is selected. High efficiency green irrigation technology should be used, such as sprinkler irrigation and micro irrigation. Collect and separate the toxic and harmful residue separately; put the hazardous waste to the relevant qualified enterprises. Setting up an emergency management plan for environmental pollution[7].

In the comprehensive utilization of resources, non traditional water sources should be used for toilet flushing, green irrigation, road spraying, car washing and cooling. Measures for reuse of solid waste resources, such as dredged soil and sludge comprehensive utilization, are adopted.

In terms of ecological protection, the terminal frontiers should be equipped with the receiving facilities of ship pollutants and ensure their normal use. Meanwhile, port operators should actively plant all kinds of vegetation, ensure the greening of the port area and participate in the surrounding ecological environment protection activities[8].

\section{Results and Discussion}

Tianjin port is the largest artificial port in China. It is also one of the most important ports in the north of China. It has a huge energy consumption. If we do not take all kinds of measures of environmental protection and energy saving and emission reduction as soon as possible, we will consume a lot of resources and energy and have a great impact on the environment. Therefore, the construction of green port in Tianjin port has important practical significance and strategic significance.

\section{Acknowledgment}

Fund Project,Central-level nonprofit scientific research institutes basic research project special funds TKS170207.

\section{References}

1. Fang X S,Luo X J,Zhou W F: Analysis and prospect of automated container terminal environmental protection. Port \& Waterway Engineering z1, 9-13 (2016).

2. Fan X S,He P,Chen F,Hang L H: Technical solutions for strategic environmental assessment on ecological carrying capacity-coastal ports master plan. China Environmental Science 5,1971-1978 (2017).

3. Nie J L: How to Promote the Development of Green Port in Shenzhen. China Opening Journal, 6,67-69 (2017).

4. Ouyang B,Zhu L: Study on green port development strategy in China. China Harbour Engineering, 4, 66-73 (2014).

5. Xue B L,Yu H B: Practice of Cleaner Production Aduit for The Ports. Environmental Engineering, 9, 160-163 (2017). 
6. Wu X Y:Emporcal Analysis of Green Port Construction: illustrated with Public Port of jiangyin shengxia port Group, stics Technology,9,29-32 (2013)

7. Zhu L: Analysis on Energy Saving and Emission Reduction of Clean Energy Technology in Portscontainer terminal for example. Energy Conservation \& Environmental Protection in Transportation, 5 34-36 (2017).

8. Zhang Y: Some Problems Analysis of our Country Port Coal Transportation System Design. Coal Technology 5, 145-147 (2013). 